\title{
Factors limiting the implementation of mechanical harvesting of sugarcane in Campos dos Goytacazes, RJ, Brazil
}

\author{
Cristóbal Soto Solano ${ }^{*}$, Niraldo José Ponciano ${ }^{1}$, Hamilton Jorge de Azevedo ${ }^{2}$, Paulo Marcelo de Souza ${ }^{1}$ \\ 10.1590/0034-737X201764010006
}

\begin{abstract}
The objective of this research was to identify and characterize the main technical factors that affect the deployment of the mechanized harvesting of sugarcane in Campos dos Goytacazes, Rio de Janeiro, Brazil. In general, it can be stated there were restrictive factors related to machinery, administrative management, and technical planning. We identified significant technical restrictions in the planting system, particularly in relation to the size and shape of the plots, length of the rows, row spacing, and inadequate varieties. For efficient use of mechanized harvesting, a technical planning is necessary with changes in the cropping system, adopting wider and more uniform plots regarding to its format, with rows over $500 \mathrm{~m}$ length and row spacing of $1.50 \mathrm{~m}$ and upright, productive, and deep-rooted varieties.
\end{abstract}

Key words: management of mechanized operations; technical and field aspects.

\section{RESUMO}

\section{Fatores limitantes da implantação na colheita mecanizada da cana-de-açúcar em Campos dos Goytacazes, RJ}

Objetivou-se identificar e caracterizar os principais fatores técnicos que afetam a implantação do sistema de colheita mecanizada no Município de Campos dos Goytacazes, RJ. De maneira geral, pode-se afirmar que existem fatores restritivos relacionados às máquinas, à gestão administrativa e planejamento técnico. Identificaram-se importantes restrições técnicas no sistema de plantio adotado, principalmente no que se refere ao tamanho e formato dos talhões, ao comprimento das fileiras, ao espaçamento entre fileiras e variedades inadequadas. Para utilização eficiente da colheita mecanizada será necessário planejamento técnico com mudanças no sistema de plantio, adotando talhões maiores e mais uniformes com relação ao formato, com fileiras acima de $500 \mathrm{~m}$ de comprimento, e espaçamento entre fileiras de $1,50 \mathrm{~m}$, adoção de variedades eretas, produtivas e de raízes profundas.

Palavras-chave: gerenciamento de operações mecanizadas; aspectos técnicos e de campo.

Submitted on July $24^{\text {th }}, 2014$ and accepted on December $19^{\text {th }}, 2016$.

${ }^{1}$ Universidade Estadual do Norte Fluminense, Centro de Ciências e Tecnologias Agropecuárias, Campos dos Goytacazes, Rio de Janeiro, Brazil. csoto@uenf.br; ponciano@uenf.br; pmsouza@uenf.br

${ }^{2}$ Universidade Federal Rural do Rio de Janeiro, Campos dos Goytacazes, Rio de Janeiro, Brazil. hamilton5520@hotmail.com

*Corresponding author: csoto@uenf.br

Rev. Ceres, Viçosa, v. 64, n.1, p. 040-046, jan/fev, 2017 


\section{INTRODUCTION}

The mechanization process of sugarcane harvest in Brazil began in the 1950 s, when the first stem loaders appeared. In the 1970s, this process received greater momentum with the importation of harvesting machines and the production of self-propelled machines (Ripoli \& Ripoli, 2009).

According to Costa et al. (2009), there has been great expansion of the sugarcane agroindustrial system in Brazil since the 1990s. The increase in the world demand for sugar and the use of ethanol as an additive or even substitute for gasoline are the main factors responsible for the growth of the sector.

However, in the last decade, the sugar and alcohol sector in the state of Rio de Janeiro significantly reduced its share in the Brazilian market. The production of raw material decreased from 7,576.4 thousand Mg in 2004 to 2,007.6 thousand $\mathrm{Mg}$ in 2013, with average productivity of only $51.4 \mathrm{Mg} \mathrm{ha}^{-1}$, while the national average is around 74.8 $\mathrm{Mg} \mathrm{ha}^{-1}$ (CONAB, 2013).

The use of sugarcane field burning facilitates the harvesting by eliminating the excess of dry straw. However, it has generated negative effects on the environment and on the inhabitants of the sugarcane-producing regions. In this sense, the pressures of environmentalists and even the Public Prosecutor's Office have been increasing for programmed reduction, culminating in the prohibition of the use of fire in the sugarcane harvest by the year 2020 (SEAPEC, 2015).

In this context, studies show that the mechanical harvesting of raw sugarcane can bring economic benefits and avoid environmental and public health damages by not burning the straw (Ronquim, 2010).

On the other hand, there have been concerns about the loss of raw material quality by the presence of vegetable and mineral impurities due to the variety of sugarcane, soil conditions, and the type of machine used with its specificities in the base cutting systems and cleaning (Magalhães et al., 2008).

Almeida et al. (2009) concluded that the systematization of the lands contributes to the success of the mechanical harvesting of sugarcane, noting that in adequately systematized fields, there are lower levels of losses compared with commercial sugarcane plantations. Nonsystematized plots, as well as dead and non-parallel rows, affect the performance of the machines by increasing the number of manoeuvers.

Ripoli \& Ripoli (2009) recommend that in the acquisition of sugarcane harvesters, factors involved in the operational capacity, design characteristics, planning, administrative management, and field conditions should be considered. The planning and execution actions should start with the correct selection of varieties, the local edafo-climatic conditions, and the aspects related to the transportation and reception of the raw material in the industry. In addition, the training of quality operational labor or its availability in the region should be considered.

According to Benedini \& Conde (2008b), the success of the harvest is due to several field factors, among them: soil levelling, shape and length of plots, productivity and homogeneity of the sugarcane field, cultivars with desirable characteristics for mechanized cutting, operation quality, and operator training.

Mattos (1992) emphasized the importance of agricultural planning due to the introduction of mechanized harvesting with the choice of planting area, of a slope of less than $12 \%$, soil preparation, removal of physical barriers (stumps, stones, etc.), planting system, and row spacing.

In an attempt to reduce costs, improve the profitability of the sector, reduce labor shortages, and comply with environmental legislation, sugarcane mills and producers have opted for a gradual mechanization of harvesting. Thus, the present work aims to analyze the main technical factors that affect the implementation of mechanized harvesting system in Campos dos Goytacazes, state Rio de Janeiro, Brazil.

\section{MATERIAL AND METHODS}

The area chosen for the study is located approximately $8 \mathrm{~km}$ from Campos dos Goytacazes - RJ, in the neighboring regions of the lands administered by the Santa Cruz, Sapucaia Industry and independent producers, in an area of $88 \mathrm{Km}^{2},-21.6750^{\circ}$ latitude and $-41,4100^{\circ}$ longitude.

The evaluation of the factors and field conditions that interfere in the operational capacity of the harvesters and that influence the viability of the mechanized harvest of sugarcane in Campos dos Goytacazes was carried out in two stages. In the first one, from the characterization of the study area, the main viability parameters of this harvesting system were selected, namely: slope, area, length, width, and irregularity of the plots. Regarding the crop, the following parameters were selected: cultivated area, varieties, productivity, and row spacing. In the second step of the methodological process, a detailed analysis of the selected parameters and a numerical treatment that quantified them in a more specific way was sought.

A high-resolution satellite image (Quick Bird, 0.6 by 0.6 m pixel) generated in 2008 and acquired at Empresa Imagem Sistemas de Informação Ltda. was used to survey the selected parameters. In the survey, the use of soil was considered in the following characteristics: forests, trails, water, pasture, road network, network of canals and drainage, and other uses for delimiting the fields planted with sugarcane. 
The numerical quantification, divided into classes or categories, according to the interest analysis, allowed to obtain the values of the attributes, as well as greater possibilities of data analysis and importance of each indicator.

The tool used in this analysis process was the Geographic Information System ARC_GIS 9.2 (Solano, 2011). The nominal work scale was from 1 to 3 thousand and for each of the fields with sugarcane, the parameters analyzed were determined. Other complementary data were obtained by consulting information from the database of the Santa Cruz, Sapucaia, and Fluminense mills and the Associação Fluminense dos Plantadores de Cana ASFLUCAN, and field checks with the producers.

The size of the plots was determined by the area calculation, in which the ARC_GIS programming routine automatically calculated this value for each polygon. The values obtained were normalized to a range from 0 to 20 ha and divided into ten categories or classes. The indicator of the plot shape is composed of three parameters obtained by equation 1 , which qualifies the irregularity (Ki) as the ratio between the area of the plot (A) and the maximum width $(\mathrm{Wm})$ by the maximum length $(\mathrm{Lm})$ of the plot.

$K i=\frac{A}{W m * L m}$

For the determination of this data, representative lines of these elements were drawn in the image with the help of the "metric operations" tool of the ARC_GIS and the results were individually tabulated for later normalization. The result is a dimensionless value indicative of the irregularity of the plot, whose maximum value is equal to the unit. A plot with low coefficient of irregularity is more prone to lower operational efficiency than another of the same size, but with higher coefficient of irregularity. The values obtained were normalized to a range of 0.0 to 1.0 and divided into ten categories or classes, with the highest value of Ki corresponding to a square or rectangular area; as the coefficient of irregularity decreases its shape, it tends to be more irregular, going through the triangular shape of $\mathrm{Ki}$ around 0.5 .

In order to calculate the slopes of the area of each plot (polygon), a grid of altimetric dimensions was transported to ARC GIS, based on contour lines from 1 to 10 thousand. According to the shapes of the plots, the slopes were also determined using the "metric operations" tool of the ARC GIS and the results tabulated individually. The values obtained were normalized to a range from 0 to $36 \%$ slope, divided into ten categories or classes, as described later.

The lengths of the planting rows were determined using representative lines in the image of these elements with the aid of the "metric operations" tool of the ARC GIS and the results were tabulated individually for further analysis.
The values obtained were normalized for a range of 0 to $1,000 \mathrm{~m}$ and divided into 10 categories.

With the table of these parameters, a descriptive statistical analysis of the characteristics of sugarcane plots was carried out in relation to the factors mentioned above.

\section{RESULTS AND DISCUSSION}

The total area of the 2,507 plots registered in the present study corresponds to 5,632.75 ha cultivated with sugarcane, which were quantified and normalized (Table 1).

The high amplitude values found, as well as the values of coefficients of variation, showed high variability and heterogeneity of the data sampled (Table 1). This, in turn, indicates that such factors or parameters are restrictive regarding the suitability of these areas cultivated with sugarcane to adapt the mechanized harvest, according to the results of Furlani Neto (1994) and Benedini \& Conde (2008b).

For the size and length of the planting rows of the plots, mean, median, and mode values were observed below those indicated by the survey, which represent the occurrence of many sugarcane fields with characteristics that make it difficult for the harvesters to operate (Table 1). However, the values found for field width and slope of the area were favorable to the mechanized harvesting system.

In the area sampled for the survey, forty varieties were cultivated. This indicates a high composition of planted cultivars, with production cycles ranging from twelve to eighteen months and distributed with different maturation curves (early, average, and late). Of this total sampled, we verified that the ten predominant cultivars represent $76.15 \%$, which corresponds to the planted area of $4,901.77$ ha (Table 2). It was also verified that the varieties SP801816, RB86-7515, and SP79-2233 were the most cultivated, with $14.62,12.50$, and $9.69 \%$, respectively, making a planted area of 2,368.99 ha.

In the harvest planning for the mechanical cutting of sugarcane, it is important to select upright, vigorous varieties with difficulty to tip and uniformity of the stems, easy defoliation, and deep root system, in order to facilitate the cutting of the base and the effective capacity of the harvester.

In this sense, Furlani Neto (2000) recommended the following varieties, considered suitable for the mechanical cutting for the Central South region: RB85-5113; RB86-7515; RB83-5486, RB85-5453, RB85-5595; RB85-5035; RB85-5536, RB85-5036; RB84-5197, and RB84-5210 of the Inter-University Network for the Development of the Sugar and Alcohol Sector - RIDESA, varieties SP81-3250, SP80-1842, SP86-155; SP801816; SP80-3280, and SP79-2233, from the Sugarcane Technological Center - CTC, and the variety IAC87-3396 from the Agronomic Institute of Campinas - IAC.

It is important to note that only cultivars RB86-7515, SP81-3250, SP80-1816, and SP79-2233 were within the study area and represented $42.20 \%$ of the total analyzed, which 
Table 1: Statistical data of the field factors studied for the definition of coefficients and quantitative indicators

\begin{tabular}{lccrr}
\hline & Size (ha) & Length $(\mathbf{m})$ & Width $(\mathbf{m})$ & Slope $(\boldsymbol{\%})$ \\
\hline Minimum & 0.01 & 7.00 & 5.00 & 0.50 \\
Median & 1.85 & 247.00 & 85.00 & 0.50 \\
Maximum & 19.55 & 885.00 & 521.00 & 35.00 \\
Mean & 2.25 & 250.40 & 103.20 & 2.20 \\
Mode & 0.32 & 360.00 & 82.00 & 0.50 \\
Standard deviation & 2.00 & 115.80 & 58.80 & 3.60 \\
Coefficient of variation (\%) & 88.88 & 46.24 & 56.97 & 163.63 \\
\hline
\end{tabular}

corresponded to a planted area of $2,716.20$ ha (Table 2). According to Miller (2008), the recommendation is to use a relatively large number of varieties, each of which occupying considerable areas, but never exceeding $20 \%$ of the total area planted.

The most representative varieties within the study area did not exceed the occupancy limits recommended by the researchers (Table 2). However, there were problems in planting planning that culminated in the mismatch of harvesting due to the limitation of early and late varieties. Thus, the cultivated varieties presented only average and late maturity curves.

Regarding the size of the plots, it is observed that approximately $90 \%$ of the plots studied grouped areas equal to or less than 4 ha (Figure 1). Of this total, 60.19\% had areas under 2 ha.

In the area sampled for the research, it was verified that the plots had reduced sizes (Figure 1). The two categories of smaller plots (0-2 and 2-4 ha) constituted the greater part of the cultivated area $(67.46 \%)$, making a total area of 3,799.58 ha cultivated with sugarcane (Table 3).

It was noted that the size of the reduced plots was a limiting factor to the mechanization of the sugarcane harvest. According to Benedini \& Conde (2008b), the harvester performs efficiently when the length of the plot rotates around 500 to $700 \mathrm{~m}$ and when the width is in a range of 140 to $400 \mathrm{~m}$. Based on the constraint slope of the

Table 2: Main sugarcane varieties cultivated in the study area distributed by planted area and their respective percentage

\begin{tabular}{lcc}
\hline Variety & Area (ha) & Share $(\boldsymbol{\%})$ \\
\hline SP80-1816 & 941.14 & 14.62 \\
RB86-7515 & 804.42 & 12.50 \\
SP79-2233 & 623.43 & 9.69 \\
SP79-1011 & 563.86 & 8.76 \\
RB72-454 & 511.24 & 7.94 \\
SP83-2847 & 407.04 & 6.32 \\
SP81-3250 & 347.21 & 5.39 \\
RB92-8064 & 321.70 & 5.00 \\
RB75-8540 & 208.49 & 3.24 \\
RB86-5547 & 173.24 & 2.69 \\
\hline Total & 4901.77 & 76.15 \\
\hline
\end{tabular}

ground, for a high efficiency of the machine, each plot could not be smaller than 10 ha.

The statistical data related to the length of the plot presented high variability, whose minimum and maximum values corresponded to 7.0 and $885.0 \mathrm{~m}$, respectively, a modal value of $360.0 \mathrm{~m}$ and the mean around $250.4 \mathrm{~m}$ in length. It could be observed that the length of the rows was also quite restrictive, since $56 \%$ of the plots were 200 to $400 \mathrm{~m}$ long (Figure 2).

There was a great heterogeneity and most of the plots were outside the standardization recommended for mechanization of the sugarcane harvest (Table 4). Only 180 plots $(7.18 \%)$ had length of planting rows above 400 $\mathrm{m}$. In terms of extension, this corresponded to $1,070.88$ ha (19.01\%) of the studied area.

For Furlani Neto (1994), the greater efficiency of the machine occurs with lengths above $400 \mathrm{~m}$. Below this magnitude, the operational capacity is reduced, significantly reducing the cost of harvest mechanization. In addition, it was found that the majority of the loaders had a width of around $5 \mathrm{~m}$. For the mechanized cutting of raw sugarcane, Benedini \& Conde (2008b) recommended width of 7 to $8 \mathrm{~m}$ for the main loaders. Ripoli \& Ripoli (2009) recommend width of 7 to $10 \mathrm{~m}$ depending on the turning radius of the machine. Thus, both the length of the planting rows and the width of the loaders are restrictive factors for the mechanization of the sugarcane harvest.

Table 3: Physical distribution of the size of the plots, planted area, and share in relation to the total area studied

\begin{tabular}{lcc}
\hline Plot size (ha) & Planted area (ha) & Share $(\boldsymbol{\%})$ \\
\hline $0-2$ & $1,432.97$ & 25.44 \\
$2-4$ & $2,366.61$ & 42.02 \\
$4-7$ & $1,024.19$ & 18.18 \\
$7-9$ & 498.09 & 8.84 \\
$9-11$ & 165.12 & 2.93 \\
$11-13$ & 41.84 & 0.74 \\
$13-16$ & 31.74 & 0.56 \\
$16-18$ & 52.66 & 0.93 \\
$18-20$ & 19.53 & 0.35 \\
\hline Total & $5,632.75$ & 100 \\
\hline
\end{tabular}

Rev. Ceres, Viçosa, v. 64, n.1, p. 040-046, jan/fev, 2017 
The high variability in the shape of the plots, found within the study area, was mainly due to a wide network of irrigation and drainage channels and the existing road network. In addition to this, the adopted conservationist practice has also favored the appearance of "dead streets", without parallelism with the earth roads, thus contributing to a greater variation of the shape of the plots, which compromises the operational performance of the harvesters (Figure 3).
Regarding the shape, the plots were classified into categories according to conventional shapes, namely: square, rectangular, parallelogram, trapezoidal, triangular, and irregular shape. The more irregular the field is, the greater the magnitude of its coefficient. Thus, the squarerectangular shape has Ki values of 0.96 to 1.00; parallelogram ranging from 0.90 to 0.95 ; trapezoidal shape with values from 0.85 to 0.89 ; and triangular shape with $\mathrm{Ki}$ values of 0.45 to 0.55 (Solano, 2011).

Table 4: Physical distribution of the number and length of the plots, planted area, and percentage share in relation to the total area studied

\begin{tabular}{lccc}
\hline Number of plots & Length $(\mathbf{m})$ & Area $($ ha) & Frequency $(\boldsymbol{\%})$ \\
\hline 264 & $0-100$ & 89.87 & 1.60 \\
664 & $100-199$ & 724.24 & 12.86 \\
707 & $199-299$ & $1,511.75$ & 26.84 \\
692 & $299-398$ & $2,236.01$ & 39.70 \\
124 & $398-498$ & 610.78 & 10.84 \\
44 & $498-597$ & 353.16 & 6.27 \\
11 & $597-697$ & 95.60 & 1.70 \\
0 & $697-796$ & - & - \\
1 & $796-896$ & 11.34 & 0.20 \\
\hline Total & 2,507 & $5,632.75$ & 100.00 \\
\hline
\end{tabular}

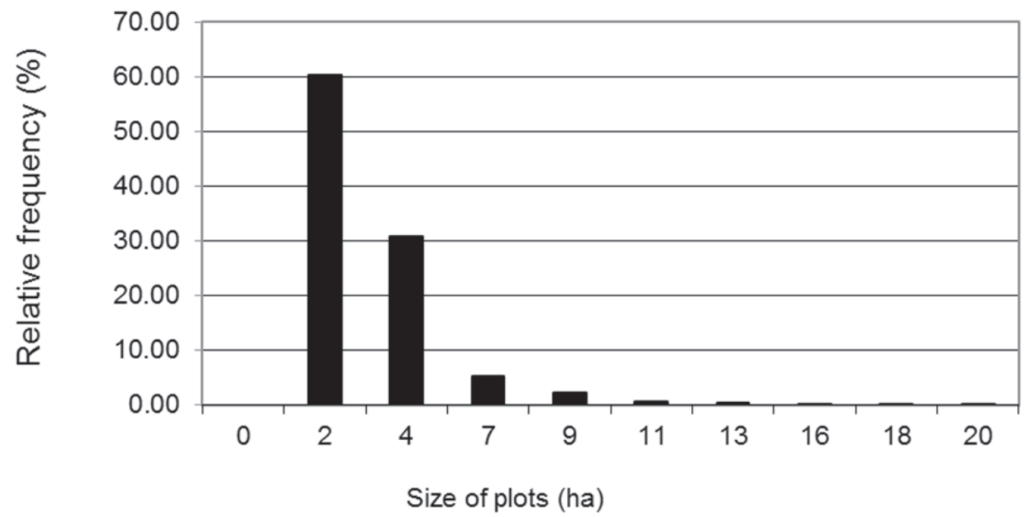

Figure 1: Distribution of the values related to the size of the blocks divided into ten categories

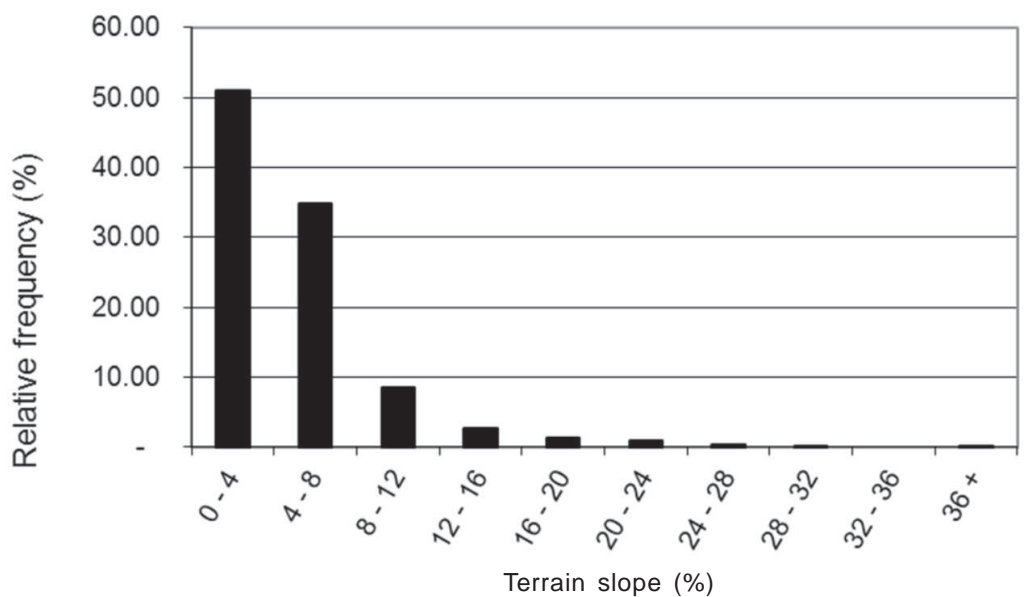

Figure 2: Graphical representation of the frequency distribution of plot lengths in ten categories with a range of approximately $100 \mathrm{~m}$. 
Low irregularity is considered when the coefficients vary from 0.56 to 0.84 and high irregularity when the coefficients of irregularity are in the range of 0.3 to 0.44 (Solano, 2011). In this sense, $45.40 \%$ of the plots, corresponding to a planted area of $2,566.14$ ha (45.56\%), presented Ki below 0.85 , thus constituting irregular shapes (Table 5).
The machine operations and implements throughout the crop cycle, from soil preparation, furrowing, and planting, through cultivation and harvesting, are affected by the unevenness of the plots. Thus, planning the entire area by dividing the plots more homogeneously (rectangular) would provide greater efficiency in all mechanized operations.

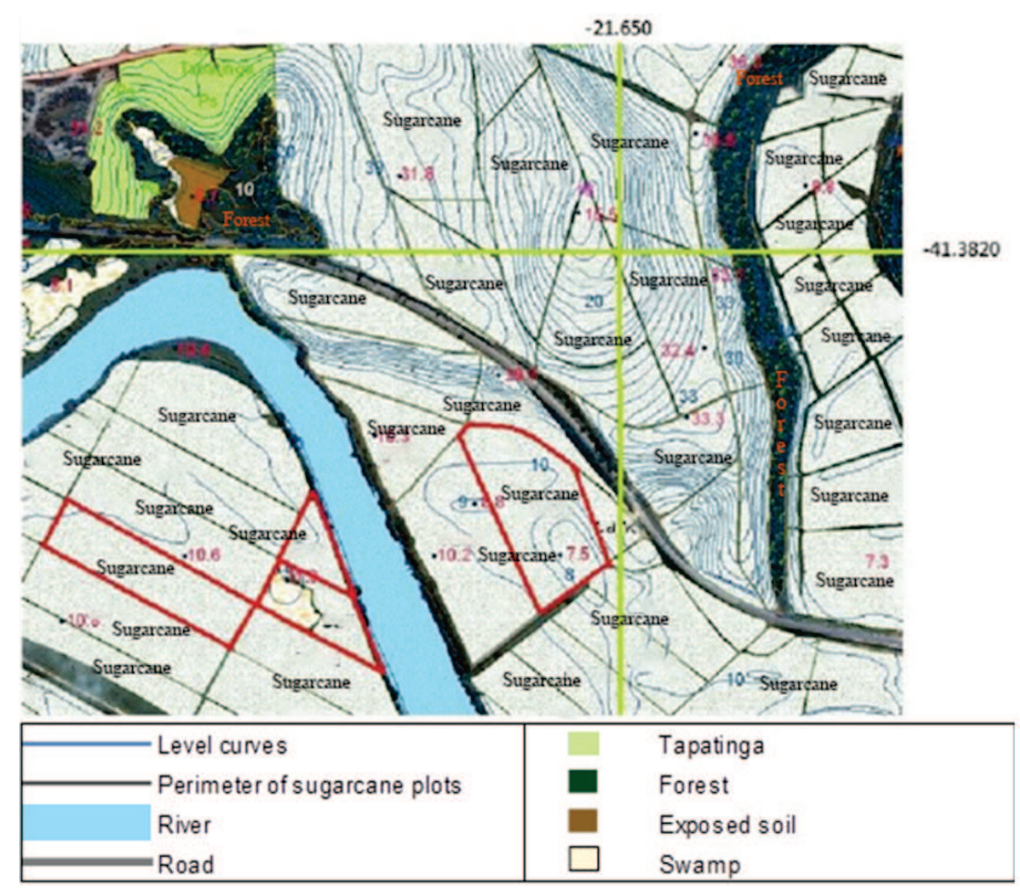

Figure 3: Spatial distribution of sugarcane fields represented by polygons in different shapes and sizes (red and green traces) and contour lines (blue) evaluated for the calculation of the coefficient of irregularity.

Table 5: Physical distribution of the number of plots, irregularity coefficient, planted area, and percentage share in relation to the total area studied

\begin{tabular}{lccr}
\hline Number of plots & Ki (dimensionless) & Frequency (\%) & Area (ha) \\
\hline 0 & $0.0-0.29$ & 0.00 & 0.00 \\
67 & $0.30-0.44$ & 2.71 & 120.29 \\
103 & $0.45-0.54$ & 4.11 & 328.84 \\
968 & $0.55-0.84$ & 38.61 & $2,117.01$ \\
238 & $0.85-0.89$ & 9.49 & 556.60 \\
400 & $0.90-0.94$ & 15.96 & $1,046.16$ \\
731 & $0.95-1.00$ & 29.12 & $1,463.85$ \\
2.507 & & 100.00 & $5,632.75$ \\
\hline
\end{tabular}

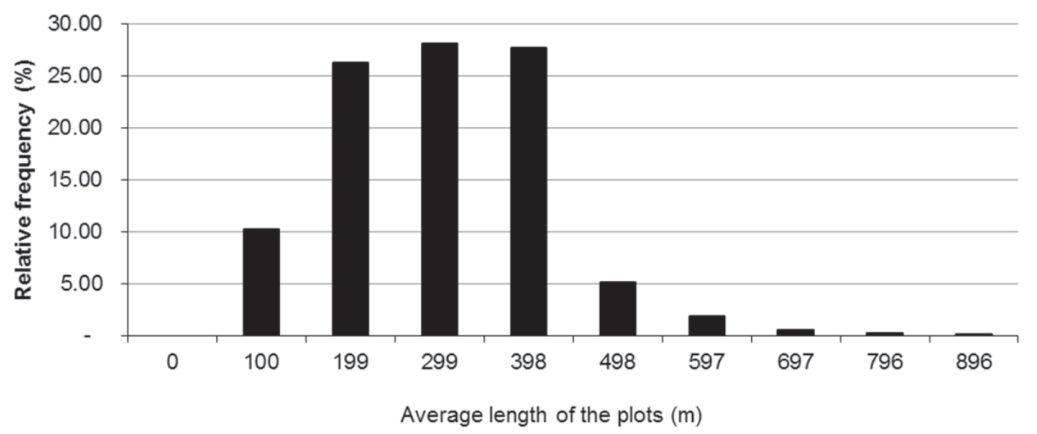

Figure 4: Relative frequency distribution of the terrain slope for the ten categories selected 
As for the terrain slope, $97.13 \%$ of the plots had a low slope, that is, up to $12.00 \%$ slope (Figure 4). Sugarcane harvesters operate on flat fields and slopes that do not exceed $12 \%$. Harvesters working in field conditions with a slope higher than that are at risk of accidents due to tipping (Torrezan 2006). Of the study area, only $5.39 \%$, or 314.61 ha, presented lands with a slope not suitable for the movement of the harvesters. Thus, the slope of the land was not a limiting factor for the use of mechanized harvesting.

Regarding the row spacing, we verified the lack of double planting lines; however, $3,875.33$ ha $(68.80 \%)$ of the cultivated area had a spacing of $1.50 \mathrm{~m}$ between rows (Table 6). According to Benedini \& Conde (2008a), this is the ideal spacing because it allows a harvest without damages to the ratoons and, consequently, greater longevity to the sugarcane field. About $30.00 \%$ had spacing smaller than $1.50 \mathrm{~m}$. This reduced spacing (1.00 to $1.40 \mathrm{~m}$ ), in turn, increase the traffic of the harvester and the accompanying vehicles, which compact the soil and cause damage to the ratoons (Benedini \& Conde, 2008a).

Table 6: Spacings used between planting lines with their respective areas in hectares and percentage

\begin{tabular}{lrc}
\hline Spacing (m) & Area (ha) & Share $(\boldsymbol{\%})$ \\
\hline 1.0 & 629.75 & 11.18 \\
1.4 & $1,127.67$ & 20.02 \\
1.5 & $3,875.33$ & 68.80 \\
\hline Total & $5,632.75$ & 100.00 \\
\hline
\end{tabular}

\section{CONCLUSIONS}

Constraints were identified in the plantation adopted, the size and shape of the plots, the length of the rows, and the varieties used.

The variables analyzed presented high variability and heterogeneity that affect the adaptability to the mechanized harvest.

Cultivated varieties proved to be unsuitable in terms of ripeness, which reduce the operating efficiency of harvester.

Slope and row spacing favored mechanized harvesting.

It can be concluded that the size of the field and the length of planting rows are reduced, which limit the efficiency of the harvester and increases the operational cost of mechanization.

For efficient utilization of mechanized harvesting, technical planning with changes in the planting system will be necessary, with the adoption of larger and more uniform plots with respect to the shape, with longer rows and row spacing of $1.50 \mathrm{~m}$, adoption of upright, productive varieties of deep roots.

\section{REFERENCES}

Almeida BR, Ripolli TCC \& Neves EM (2009) Avaliação das perdas de cana-de- açúcar na colheita mecanizada em diferentes condições de sistematização de terreno. Disponível em: <http:/ /www.usp.br/siicusp/Resumos/17Siicusp/resumos/2773.pdf >. Acessado em: 18 de abril de 2010.

Benedini MS \& Conde AC (2008a) Espaçamento ideal de plantio para a colheita mecanizada da cana-de-açúcar. Revista Coplacana, 52:26-28.

Benedini MS \& Conde AC (2008b) Sistematização de área para a colheita mecanizada de cana-de-açúcar. Revista Coplacana, $53: 23-25$.

CONAB - Companhia Nacional de Abastecimento (2013) Acompanhamento da safra brasileira de cana-de-açúcar. Disponível em: <http://www.conab.gov.br/OlalaCMS/uploads/arquivos/ 14_04_15_15_44_37_boletim_cana_portugues_-_10_lev__14.pdf >. Acessado em: 20 de maio de 2014.

Costa JAB, Ponciano NJ, Souza PM \& Ribeiro AC (2009) Avaliação da competitividade do sistema agroindustrial da cana-deaçúcar na região norte fluminense. In: XLVII Congresso da Sociedade Brasileira de Economia, Administração e Sociologia Rural, Porto Alegre. Anais, SOBER. p.1-22.

Furlani Neto VL (1994) Colheita mecanizada da cana-de-açúcar. Revista STAB, 12:8-16.

Furlani Neto VL (2000) Sistematização e adequação de áreas e maquinas para colheita mecanizada. In: 5 ${ }^{a}$ Reunião Agrícola Fermentec, Piracicaba. Anais, Fermentec. CD-ROM.

Magalhães PSG, Baldo RFG \& Cerri DGP (2008) Sistema de sincronismo entre a colhedora de cana-de-açúcar e o veículo de transbordo. Engenharia Agrícola, 28:274-282.

Mattos JR (1992) Planejamento da lavoura para implementação e operacionalização mecânica da cana-de-açúcar. In: $8^{\circ}$ Encontro Técnico do grupo de trabalho de mecanização no setor sucroalcooleiro, Ribeirão Preto. Anais, mimeografado. n.p.

Miller LC (2008) Tecnologia Agrícola para Exploração e Manejo da Lavoura da Cana-de-Açúcar. Colheita. Parte 4. Disponível em: <http://www.sigacana.com.br/d_colheita/4.planej_e_ oper_da_colheita_de_cana_industrial_atualiz.htm>. Acessado em: 22 de julho de 2010.

Ripoli TCC \& Ripoli MLC (2009) Biomassa de cana-de-açúcar: colheita, energia e ambiente. $2^{\text {a }}$ ed. Piracicaba, ESALQ/USP. $333 \mathrm{p}$.

Ronquim CC (2010) Queimada na colheita de cana-de-açúcar: impactos ambientais, sociais e econômicos. Campinas, Embrapa Monitoramento por Satélite. 45p. (Documento, 77).

SEAPEC - Secretaria de Estado de Agricultura e Pecuária. STF garante eliminação gradual da queima da cana-de-açúcar. Disponível em: <http://www.rj.gov.br/web/seapec/exibeconteudo? article-id=2356744> . Acessado em: 17 de maio de 2016.

Solano SC (2011) Avaliação técnica e econômica dos sistemas de colheita da cana-de-açúcar no município de Campos dos Goytacazes, RJ. Dissertação de Mestrado. Universidade Estadual Norte Fluminense, Campos dos Goytacazes. 121p.

Torrezan HF (2006) Colheita mecanizada da cana de açúcar. Atualização em produção de cana-de-açúcar. Piracicaba, ESALQ/ USP. $415 \mathrm{p}$. 